\title{
The Influence of Travel Agent, Infrastructure and Accommodation on Tourist Satisfaction
}

\author{
Juliater Simarmata, Yuliantini, and Yulianti Keke \\ STMT Trisakti \\ Jakarta. Indonesia \\ juliaters@gmail.com
}

\begin{abstract}
The aim of this research is to examine and find out the influence of travel agent, infrastructure and accommodation on tourism satisfaction visiting tourist attraction bukit lawang North Sumatera. The population in this study are all the tourists visiting Bukit Lawang, the number of samples set $10 \mathrm{X}$ indicator $(10 \times 23)=230$. Data is collected through an interview, questionnaire, and documentation study; the variables are studied using 5-score likert scale. The questionnaire is tested first using validity test and reliability test as well as model fitness test; data processing uses the software of Statistical Product and Service Solutions (SPSS), and it is analyzed using multi regression. The results of hypothetical test in this research are as follows: simultaneously, travel agent, infrastructure and accommodation significantly influence on the satisfaction of the tourists visiting the attractive tourism place of Bukit Lawang in North Sumatera. In partial, travel agent and infrastructure significantly influence on the satisfaction of the tourists visiting the attractive tourism place of Bukit Lawang in North Sumatera and accomodation has no significant influence on the satisfaction of the tourists visiting the attractive tourism place of Bukit Lawang in North Sumatera.
\end{abstract}

Keywords - travel agent, infrastructure, accommodation, tourist satisfaction.

\section{INTRODUCTION}

Today, the Indonesian tourism industry is being paid serious attention by the government. The government has been seriously and fast developing various infrastructures such as airport, terminal, toll road (highway), and so on. The infrastructure development is also intended for developing the Indonesian tourism industry.

North Sumatera is one of the provinces which is now paid serious attention by the government in infrastructure development, among others are toll highway Medan-Tebing Tinggi, toll highway Medan-Binjai, airport, harbour, and so on. The infrastructure development is also expected to be able to increase the number of tourists who visit various tourism objects in North Sumatera.

Of course, Bukit Lawang as a tourism object in North Sumatera today does not escape the government's attention. However, up to now there are still many obstacles causing the decreasing number of visitors to the tourism object of Bukit Lawang. For example, the availability of accommodation or around the tourism object has not been able to fulfill the tourists' need; the road has not been smooth and the toll highway construction of Medan-Binjai has not completed; as well as the travel agents have not been able to fulfill the potential tourists' needs. The aim of this research is to examine and find out the influence of travel agent, infrastructure and accommodation on tourism satisfaction visiting tourist attraction bukit lawang North Sumatera.

\section{LITERATURE REVIEW}

According to Monaghan (2006), Travel Agent is a business entity which holds travel business as the intermediary in selling or arranging travel services. The main products of travel agent are ticketing, hotel voucher, tour package, show voucher, and tour transport. Meanwhile, Nyoman (1994) states that Travel Agent is a business of services which has a goal to provide a travel for someone who plans to make it.

Infrastuctures are any facilities which enable the process of economy to run so smoothly that it makes people easy to fulfill their needs. Tourism infrastructures are natural resources and human resources which are absolutely needed by the tourists in their travel to the tourist destination, such as road, electricity, water, telecomunication, health services, terminal/harbour, and so on (Suwantoro, 2004: 21).

Accommodation is something provided to fulfill what needed, for example a place for stay or temporary residence for those who are traveling (Setzer Munavizt, 2009)

Tourist accommodation, according to Burkart and Medlik (1987), refers to two inseparable components. The two components are supply and demand. It shows that tourist accommodation refers to who serves the needs of tourists or tourism consumers. Tourist accommodation according to Burkart and Medlik is classified into four categories, namely: a) service accommodation, the accommodation in the form of service including hotel, apartment, guest house, and boarding house; b) Self-catering accommodation, the accommodation that requires its consumers to provide their meals, such as camping, caravans, rented flats, and houses; c) House of friends and relatives, in this case accommodation does not need any cost because it has been provided by a friend, relative or family in the destination area; and d) Other accommodations, including hostels, youth hostels, boats, and so on.

According to Kotler (2000), customer satisfaction is the level of feelings someone has after having compared the performance (or result) he or she feels to his or her expectation. Gaspersz (2005) states the factors influencing customer 
satisfaction and expectation consist of: "need and want" related to the things experienced by the customer when he or she is trying to make a transaction with the service producer.

\section{A. Conceptual Framework} the figure 1 .

The paradigm of this research is briefly illustrated as

\section{B. Research Hypoteses}

Based on the background and the conceptual framework, the research hypotheses can be formulated as follows:

1. Travel agent, tourism infrastructure, and accommodation simultaneously have a positive and significant influence on the satisfaction of the tourists who visit the tourist object of Bukit Lawang in North Sumatera.

2. Travel agent has a positive and significant influence on the satisfaction of the tourists who visit the tourist object of Bukit Lawang in North Sumatera.

3. Tourism infrastructure has a positive and significant influence on the satisfaction of the tourists who visit the tourist object of Bukit Lawang in North Sumatera.

4. Accommodation has a positive and significant influence on the satisfaction of the tourists who visit the tourist object of Bukit Lawang in North Sumatera.

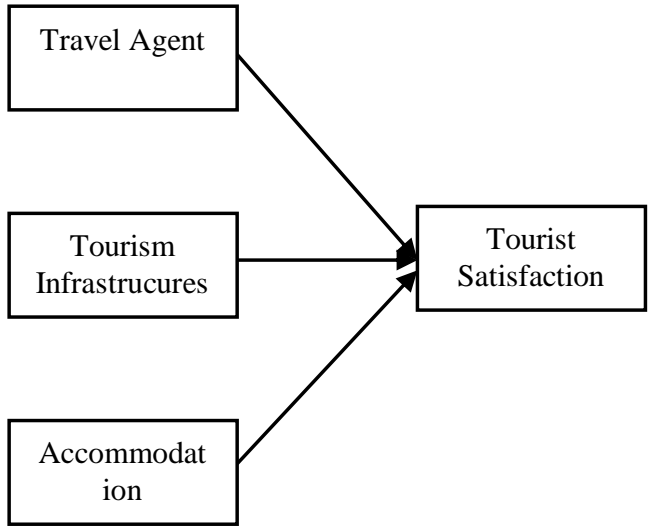

Fig. 1. Research Paradigma

\section{METHODS}

The object of this research consists of travel agent, tourism infrastructure, accommodation, and tourist satisfaction. The research location is the tourist object of Bukit Lawang in North Sumatera. This research is descriptive quantitative. Nazir (2005) states that descriptive research is a method of studying the status of a group of human beings, a thought, or a class of phenomenon in the recent time aimed at making description, illustration, or depiction in a systematic, factual and accurate way concerning the facts, natures and relationship among the phenomena being studied.

The definition of descriptive analysis according to Sugiyono (2005: 1) is: research carried out to find out the value of independent variable(s), either one or more, without making any comparison or relating one variable to another. In this research, descriptive analysis method is used to examine each of the independent variables, namely travel agent $\left(\mathrm{X}_{1}\right)$, infrastructure $\left(\mathrm{X}_{2}\right)$, and accommodation $\left(\mathrm{X}_{3}\right)$, as well as to examine the dependent variable, namely the satisfaction of the tourists who visit Bukit Lawang in North Sumatera (Y).

The population of this research is all the tourists who visit the tourist object of Bukit Lawang in North Sumatera, whereas the number of samples is set $10 \mathrm{x}$ the number of indicators; since the number of indicators is 23 , then the number of samples in this research is 230 people. The technique used for sampling is accidental sampling.

\section{RESULTS}

\section{A. Simultaneous Test (F Test)}

In order to test the hypoteses, F statistic is used with the criteria of decision making if the value of $\mathrm{F}_{\text {calculation }}$ is more than $\mathrm{F}_{\text {table, then }} \mathrm{H}_{0}$ is rejected and $\mathrm{H}_{1}$ is accepted. Based on the following table it can be seen that $\mathrm{F}_{\text {calculation }}=17.959$ and $\mathrm{F}_{\text {table }}=$ 2.64 , in this case $\mathrm{F}_{\text {calculation }}$ is more than $\mathrm{F}_{\text {table }}$ and the value of significance is 0.00 less than the value of alpha 0.05 , then it is decided that $\mathrm{H}_{0}$ is rejected and $\mathrm{H}_{1}$ is accepted. The acceptance of alternative hypothesis indicates that independent variables (travel agent, infrastructure and accommodation) can explain the variety of dependent variable (tourist satisfaction), meaning that simultaneously travel agent, infrastructure and accommodation positively and significantly influence the satisfaction of the tourists who visit the tourist object of Bukit Lawang in North Sumatera.

\section{B. Partial Test ( $t$ Test)}

In order to examine the influence of independent variables on dependent variable, a partial test is carried out by implementing $t$ test. In this research, partial test is carried out to know the influences of travel agent on tourist satisfaction, infrastructure on tourist satisfaction, and accommodation on tourist satisfaction. The test is done in two directions, using the level of significance alpha $2.5 \%$ and degree of freedom $(n-k-1)$.

Hypotesis testing is carried out by comparing the value of $t_{\text {calculation }}$ to the value of $t_{\text {table }}$ with the decision criteria as follows:

If $\mathrm{t}_{\text {calculation }}<\mathrm{t}_{\text {table }} \mathrm{H}_{0}$ is accepted or $\mathrm{H}_{1}$ is rejected

If $t_{\text {calculation }}>t_{\text {table }} \mathrm{H}_{0}$ is rejected or $\mathrm{H}_{1}$ is accepted

From the statistical calculation, the results can be seen as follows:

1. The $t_{\text {calculation value of travel agent variable (3.422) is more }}$ than the $t_{\text {table }}$ value $(3.18)$, or the sig value $(0.001)$ is less than alpha (0.025). Based on this, then $\mathrm{H}_{\mathrm{o}}$ is rejected and $\mathrm{H}_{1}$ is accepted for travel agent variable. Thus, in partial, travel agent positively and significantly influences the satisfaction of the tourists who visit the tourist object of Bukit Lawang in North Sumatera.

2. The $t_{\text {calculation }}$ value of infrastructure (4.537) is more than the $t_{\text {table }}$ value (3.18), or the sig value $(0.000)$ is less than 
alpha $(0.025)$. Based on this, then $H_{o}$ is rejected and $H_{1}$ is accepted for infrastructure variable. Thus, in partial, infrastructure positively and significantly influences the satisfaction of the tourists who visit the tourist object of Bukit Lawang in North Sumatera.

3. The $t_{\text {calculation }}$ value of accommodation (0.799) is less than the $t_{\text {table }}$ value (3.18), or the sig value $(0.425)$ is more than alpha (0.025). Based on this, then $\mathrm{H}_{\mathrm{o}}$ is accepted and $\mathrm{H}_{1}$ is rejected for accommodation variable. Thus, in partial, accommodation variable does not significantly influence the satisfaction of the tourists who visit the tourist object of Bukit Lawang in North Sumatera.

\section{CONCLUSIONS}

Based on the results of this research, conclusions can be made as follows: (1) Simultaneously travel agent, tourism infrastructure and accommodation positively and significantly influence the satisfaction of the tourists who visit the tourist object of Bukit Lawang in North Sumatera. (2) In partial, travel agent and tourism infrastructure variables positively and significantly influence the satisfaction of the tourists who visit the tourist object of Bukit Lawang in North Sumatera. (3) In partial, accommodation variable does not significantly influence the satisfaction of the tourists who visit the tourist object of Bukit Lawang in North Sumatera.

\section{REFERENCE}

Burkart, A.J. and Medlik, S. (1987). Tourism, Past, Present, and Future. London

Gamal Suwantoro. (2004). Dasar-dasar Pariwisata. Penerbit ANDI. Yogyakarta.

Gasperz, V. (2005). Lean Sigma Approach. Jakarta: Penerbit Erlangga

Kotler, P. (2000). Marketing Management. Millenium Edition. NJ: Pearson.

Monaghan, Kelly. (2006). Home-Based Travel Agent. 5th Edition. The Intrepid Traveler

Nasir, Moh, (2005), Metode Penelitian, Cetakan Keenam, Penerbit Ghalia Indonesia, Bogor.

Setzer Munavizt, (2009), (cited 2015 March 4th), available from:

http://pariwisatadanteknologi.blogspot.com/2010/05/jenisjenis-akomodasi pariwisata.html59. 